DOI https://doi.org/10.30525/978-9934-26-183-1-18

\title{
ТВЕРДОФАЗНА МІКРОЕКСТРАКЦІЯ РЯДУ АРОМАТИЧНИХ АЛЬДЕГІДІВ У ВОДНИХ РОЗЧИНАХ
}

\author{
Мосендз А. О. \\ аспірант кафедри аналітичної хімії \\ Київський національний університет імені Тараса Шевченка \\ Левчик В. М. \\ кандидат хімічних наук, \\ інженер кафедри аналітичної хіміі \\ Київський національний університет імені Тараса Шевченка \\ Зуй М. Ф. \\ кандидат хімічних наук, \\ доиент кафедри аналітичної хіміі \\ Київський начіональний університет імені Тараса Шевченка \\ м. Київ, Украӥна
}

Доволі поширеними сполуками, що можуть міститись у повітрі, природних водах, напоях та харчових продуктах є альдегіди. Деякі з них - компоненти природного походження, але часто вони виступають штучними добавками чи утворюються внаслідок термічної обробки. Також карбонільні сполуки з'являються в довкіллі при дії різних окисників, наприклад толуол в атмосфері може окислюватися до бензальдегіду при дії оксидів азоту. Аліфатичні коротколанцюгові альдегіди утворюються з гумусових речовин при хлоруванні природних вод. Відомо утворення альдегідів у водах при озонуванні. При очистці дезінфікуючими засобами вихідної сировини в харчові продукти потрапляють ряд шкідливих сполук, зокрема альдегіди. Відомо дослідження, автори якого намагались виявити, який із засобів спричиняє найменше утворення подібних сполук у листях салату та промивних водах [1].

Токсична дія та значення аліфатичних, ароматичних альдегідів $\epsilon$ різними [2]. Зокрема формальдегід та акролеїн навіть в малих кількостях $\epsilon$ шкідливими. Бензальдегід та саліциловий альдегід дозволені для споживання в обмежених кількостях. Вони містяться в чаях й при цьому значною мірою впливають на аромат напою. Тож перевірка вмісту певних альдегідів необхідна як для контролю рівня небезпечних сполук 
в об’єктах навколишнього середовища, так і для перевірки якості продуктів та напоїв.

Широкий спектр біологічних ефектів карбонільних сполук обумовлює їх визначення в якості біомаркерів в біологічних матеріалах. Карбонільні сполуки можуть бути присутні в біологічних зразках у зв'язку з патологічним станом (наприклад рак) чи несприятливими антропогенними факторами (зокрема куріння). Відомі дослідження 3 кількісного визначення альдегідів, наприклад пентаналю, бензальдегіду, фурфуралю (2-фуральдегіду), в сечі, сироватці та крові курців та некурців [3].

Аналіз реальних зразків передбачає необхідність концентрування й розділення, оскільки усі реальні об'єкти містять суміш летких органічних сполук, й альдегіди містяться в низьких концентраціях. Одним 3 сучасних методів пробопідготовки вважають твердофазну мікроекстракцію (ТФМЕ). Цей метод відрізняється екологічністю (не потрібне використання органічних розчинників), ефективністю, високими коефіцієнтами концентрування, а також добре сполучається 3 хроматографічними методами.

Використання ТФМЕ для концентрування сумішей альдегідів часто зустрічається в наукових міжнародних статтях, однак переважно для визначення низькомолекулярних аліфатичних альдегідів. В нашій роботі було поставлено завдання дослідити вплив усіх важливих чинників (температури і часу сорбції, впливу йонної сили, інших параметрів) на твердофазну мікроекстракцію ароматичних альдегідів.

Було досліджено взаємодію ряду ароматичних альдегідів: 2-фуральдегіду, бензальдегіду, 2,4-диметилбензальдегіду, 4-метоксибензальдегіду 3 О-(2,3,4,5,6-пентафлуорбензил)гідроксиламіном (ПФБГА), обрано оптимальні умови дериватизації для даних альдегідів: $\mathrm{pH} 4,0$; час дериватизації 20 хв. Також оптимізовані умови ТФМЕ з використанням файберу ПДМС/ДВБ. Умови мікроекстракції отримані наступні: час сорбції $30 \mathrm{xв}$, температура сорбції $60^{\circ} \mathrm{C}$, вміст висолювача $\mathrm{NaCl}$. Були розраховані кількісні характеристики для даної методики. Межі виявлення за 3s-критерієм становлять 19-25 мкг/л.

Отже, було розроблено методику газохроматографічного визначення ряду ароматичних альдегідів у водних розчинах, що включає дериватизацію з використанням ПФБГА та пробопідготовку методом ТФМЕ. Методика була застосована для визначення альдегідів у зразках чаю та кави. Правильність методики перевірено методом введенознайдено. Результати аналізу лабораторних зразків, показали, що 
розроблений метод придатний для виявлення та кількісного визначення карбонільних сполук у водних пробах.

\section{Література:}

1. Lee W.-N., Huang C.-H. Formation of disinfection byproducts in wash water and lettuce by washing with sodium hypochlorite and peracetic acid sanitizers. Food Chemistry. 2019. V. 1. P. 100003.

2. Netzeva T., Schultz W. QSARs for the aquatic toxicity of aromatic aldehydes from Tetrahymena data. Chemosphere. 2005. V. 61. № 11. P. 1632-43. DOI: 10.1016/j.chemosphere.2005.04.040.

3. Silva L. K., Hile G. A., Capella K. M., Espenship M. F., Smith M. M., De Jesús V. R., Blount B. C. Quantification of 19 aldehydes in human serum by headspace SPME/GC/high-resolution mass spectrometry. Environmental Science \& Technology. 2018. V. 52. I. 18. P. 10571-10579.

4. M. Rodigast, A. Mutzel, Y. Iinuma, S. Haferkorn, and H. Herrman. Characterisation and optimisation of a sample preparation method for the detection and quantification of atmospherically relevant carbonyl compounds in aqueous medium. Atmospheric Measurement Techniques. 2015. V. 8. № 6. P. 2409-2416. 